\title{
More trouble for Stanford's patent
}

US patent office gives reasons for refusal

\section{Washington}

Further doubt has been cast on the validity of the key Cohen-Boyer patent covering basic processes in genetic manipulation by a decision on a second patent application taken last week by the US Patent and Trademark Office. On 30 June, the office announced that the granting of the second patent, originally planned for 13 July, would be postponed (see Nature 29 July, p.409). Last week, the office took a further step in the minuet-like US patent process and notified Stanford University (acting on its own behalf and that of the University of California, San Francisco) that the second patent application was to be rejected.

The decision of the patent office seems to turn on the status and origin of the plasmid called pSC101, that first used by Cohen and Boyer as a means of cloning foreign genes in Escherichia coli plasmids. Originally, Cohen and Boyer considered that this plasmid had been derived from a naturally occurring plasmid called R6-5 by recircularization of some fragment itself produced by hydrodynamic shear.

Last week, the US patent office cited an article published by co-inventor Stanley Cohen and a collaborator in 1977 (Cohen, S.N. and Chang, A.C.Y. J. Bact. 132, 734; 1977 ) in which other possible origins of pSC101 were canvassed. The possibility of a relationship with the Salmonella plasmid SP219 was mentioned.

The patent office now says that the 1977 article "sets forth a revised view of the origin of the pSC101 plasmid. That view conflicts with the origin of pSC101 as set forth in this application"'.

The first patent, which was issued to Stanford and the University of California at San Francisco in December 1980, presumably suffers from the same potential defect. The patent office has the authority to reexamine an already-issued patent, but has only exercised this option once since it was given the authority in 1980. Alternatively, a third party could file a challenge to the first patent.

A possible counter to the patent office's objection would be to show that the plasmid was publicly available at the time of application, and thus the claims in the patent for how the plasmid is used as a starting point in the creation of recombinant plasmids does not depend on the accuracy of the recipe for making $\mathrm{pSC} 101$. This matter is open to question; Cohen and his co-worker Herbert Boyer did make the plasmid available to qualified

scientists who requested it, but with some restrictions. The patent office asked Stanford to provide data on how many scientists were supplied the plasmid and whether any were refused.

Cohen said last week that the 1977 Journal of Bacteriology article "did not admit an error in the original procedure" but rather only in the "interpretation" of where the pSC101 plasmid came from. $\mathrm{He}$

\section{Space wars at UN conference}

Vienna

Austrian Foreign Minister Willibald Pahr has called on the world scientific community to "oppose vigorously" the increased militarization of space. He was addressing the opening session of Unispace 82 , the second United Nations conference on the exploitation and peaceful uses of outer space, now meeting here. Dr Pahr had just been elected president of the conference, an honour shared with Dr Kurt Waldheim, who, in 1968, had been Austrian Foreign Secretary when the first Unispace conference was held in Vienna.

Unispace- 1 had been mainly concerned with the potential of the new space technologies. Unispace-2, fifteen years later, is interested primarily in what can be done with those technologies to improve the quality of life of mankind. An exhibition, staged parallel to the conference, shows an impressive range of space technologies.

In one respect, Unispace-2 might be considered as a showcase for the space techniques of the more developed nations, in their hopes that these benefits could be extended to the less fortunate.

UK Minister of State Kenneth Baker observed that, "Unispace is particularly significant for those countries which do not have their own space industry, but who seek quite rightly the assurance that the way that space applications are developing is of value to all"'

The prestige element was, of course, present. The Soviet exhibit was under the direction of Dr A. P. Kapitsa, son of the Nobel prizewinner. The Americans brought to their stand not only their shuttle astronaut Henry Hartsfield but also a female trainee astronaut. The American impact, however, was somewhat lessened by the recent Soviet media campaign which stressed the military aspects of the shuttle and by fears of what President Reagan's 4 July speech about a "more permanent"'US presence in space might mean - a subject on which US delegates to Unispace 82 were remarkably non-communicative.

The idea that the "demilitarization" of space was a prime prerequisite for its peaceful exploitation was taken up by many of the delegates, including the representatives of non-governmental said that procedure was totally reproducible.

Stanford has already sold one-year licences to the first patent to 73 companies. Stanford has three months to respond to the patent office's action; a Stanford official said he did not see any "insurmountable obstacles", in successfully asserting its claim.

Stephen Budiansky

organizations, who have a special session on this theme scheduled for Saturday. If, unlike its predecessor, Unispace-2 produces some concrete recommendations, the peace issue is almost certain to be among them. So far, however, no concrete proposals for the "demilitarization" of space have emerged.

Vera Rich

\section{India's space hopes}

\section{Bangalore}

India's ambitions in space remain high despite a number of setbacks. Next month, the indigenous rocket, SLV-3, will carry a 42-kg satellite during its first operational flight and next year the first Indian astronaut will fly aboard the Soviet spacecraft Salyut-7. But the country's most ambitious space project yet, the multi-purpose operational domestic satellite INSAT-1A, has been crippled by the failure of its solar sail to deploy.

INSAT-1A, the world's first civilian telecommunications, weather and direct broadcasting satellite rolled into one, was built by the Ford Aerospace Corporation under contract from the Indian Space Department and launched by the US National Aeronautics and Space Administration aboard a Thor Delta rocket. The Indian government had planned to use the satellite for meteorology, long distance communications and for broadcasting direct to remote villages, but the failure of the solar sail will reduce the satellite's lifespan to two and a half years and limit its usefulness. The Indian Space Department is hoping for better luck with INSAT-2, due for launch aboard the space shuttle in July 1983.

High hopes are also pinned on the operational launch of SLV-3, India's own solid-fuelled, four-stage rocket. After a disastrous first test flight in 1979, SLV-3 had a successful test flight in July 1980 and was partially successful in May 1981 when it placed a small satellite into an unexpectedly low orbit, thereby condemning the satellite to 9 rather than 90 days of life.

B. Radhakrishna Rao 